\title{
How can junior doctors become more effective teachers?
}

This article was published in the following Dove Press journal:

Advances in Medical Education and Practice

8 July 2015

Number of times this article has been viewed

\author{
Elliott Yann Ah-kee' \\ Robert Adrian Scott' \\ Ahad Shafi' \\ Aamir Asif Khan² \\ 'Department of Surgery, Monklands \\ Hospital, Airdrie, UK; ${ }^{2}$ Department \\ of Surgery, Glasgow Royal Infirmary, \\ Glasgow, UK
}

\section{Dear editor}

Peer-assisted learning (PAL) has progressively become omnipresent in medical education over the years and is widely considered as beneficial for both the tutors and tutees. ${ }^{1}$ Involvement in PAL schemes as medical undergraduates acts as a platform in preparing junior doctors to become the next generation of leaders in medical education. Indeed, experience gained as an undergraduate PAL tutor can be carried forward into foundation years following graduation.

However, as junior doctors with an interest in medical education, we believe that there is a lack of formal teaching training within the UK undergraduate curriculum, despite the General Medical Council's expectation that Foundation Year 1 (1st year of training following graduation in the UK) doctors should be able to "teach their peers and medical and other health and social care students [...] using appropriate skills and methods".

In order to become effective teachers, junior doctors should be familiar with basic adult-learning concepts and with the wide variety of teaching strategies that can be employed during structured teaching sessions, case presentations, and informal team discussions. A number of training courses are available to provide doctors with fundamentals of teaching, however, they tend to be very costly and out-of-reach. Integrating formal training of teaching skills into the undergraduate syllabus would ensure a seamless transition from student peer-tutor to junior doctor teacher for all new medical graduates, at entry of their foundation program. Furthermore, undergraduates with an improved knowledge of learning and teaching principles are more likely to become better learners throughout their postgraduate training. ${ }^{3}$ Such an initiative would also raise awareness of medical students that a significant aspect of their physician identity will involve teaching, and hence encourage them to develop an altruistic motivation to teach future generations of doctors.

\section{Disclosure}

The authors declare no conflicts of interest in this work.

\section{References}

1. Glynn LG, MacFarlane A, Kelly M, Cantillon P, Murphy AW. Helping each other to learn - A process evaluation of peer assisted learning. BMC Med Educ. 2006;6:18.

2. General Medical Council. The Trainee Doctor. London: General Medical Council; 2011. Available from: http://www.gmc-uk.org/Trainee_Doctor.pdf_39274940.pdf. Accessed June 6, 2015.

3. Busari JO, Scherpbier AJ. Why residents should teach: A literature review. J Postgrad Med. 2004;50(3):205-210.
Monklands Hospital, Monkscourt Ave Airdrie, North Lanarkshire ML6 0JS, UK Email elliottahkee@gmail.com 
Advances in Medical Education and Practice

Dovepress

\section{Publish your work in this journal}

Advances in Medical Education and Practice is an international, peerreviewed, open access journal that aims to present and publish research on Medical Education covering medical, dental, nursing and allied health care professional education. The journal covers undergraduate education, postgraduate training and continuing medical education

including emerging trends and innovative models linking education, research, and health care services. The manuscript management system is completely online and includes a very quick and fair peer-review system. Visit http://www.dovepress.com/testimonials.php to read real quotes from published authors.

Submit your manuscript here: http://www.dovepress.com/advances-in-medical-education-and-practice-journal 